\title{
Transferring Nanoscale Bainite Concept to Lower C Contents: A Perspective
}

\author{
Carlos Garcia-Mateo ${ }^{1, *}$, Georg Paul ${ }^{2}$, Mahesh C. Somani ${ }^{3}$, David A. Porter ${ }^{3}$, Lieven Bracke ${ }^{4}$, \\ Andreas Latz ${ }^{2}$, Carlos Garcia De Andres ${ }^{1}$ and Francisca G. Caballero ${ }^{1}$ \\ 1 Department of Physical Metallurgy, National Center for Metallurgical Research (CENIM-CSIC), \\ Avenida Gregorio del Amo, 8, 28040 Madrid, Spain; cgda@cenim.csic.es (C.G.D.A.) \\ fgc@cenim.csic.es (F.G.C.) \\ 2 Thyssenkrupp Steel Europe, Technology \& Innovation, Modelling and Simulation, \\ Kaiser-Wilhelm-Straße 100, 47166 Duisburg, Germany; georg.paul@thyssenkrupp.com (G.P.); \\ andreas.latz@thyssenkrupp.com (A.L.) \\ 3 Materials Engineering and Production Technology, Faculty of Technology, University of Oulu, \\ 90014 Oulu, Finland; mahesh.somani@oulu.fi (M.C.S.); david.porter@oulu.fi (D.A.P.) \\ 4 ArcelorMittal Global R\&D Ghent, J.F. Kennedylaan, 9060 Zelzate, Belgium; lieven.bracke@arcelormittal.com \\ * Correspondence: cgm@cenim.csic.es; Tel.: +34-91-553-8900
}

Academic Editor: Håkan Hallberg

Received: 27 March 2017; Accepted: 28 April 2017; Published: 4 May 2017

\begin{abstract}
The major strengthening mechanisms in bainitic steels arise from the bainitic ferrite plate thickness rather than the length, which primarily determines the mean free slip distance. Both the strength of the austenite from where the bainite grows and the driving force of the transformation, are the two factors controlling the final scale of the bainitic microstructure. Usually, those two parameters can be tailored by means of selection of chemical composition and transformation temperature. However, there is also the possibility of introducing plastic deformation on austenite and prior to the bainitic transformation as a way to enhance both the austenite strength and the driving force for the transformation; the latter by introducing a mechanical component to the free energy change. This process, known as ausforming, has awoken a great deal of interest and it is the object of ongoing research with two clear aims. First, an acceleration of the sluggish bainitic transformation observed typically in high $C$ steels $(0.7-1 \mathrm{wt}$. \%) transformed at relatively low temperatures. Second, to extend the concept of nanostructured bainite from those of high $\mathrm{C}$ steels to much lower $\mathrm{C}$ contents, $0.4-0.5$ wt. \%, keeping a wider range of applications in view.
\end{abstract}

Keywords: bainite; ausforming; kinetics; plate thickness

\section{Structural Refinement of Bainitic Steels: General Considerations}

Bainitic steels can be designed on the basis of the theory that predicts the highest temperature at which bainite (Bs) and martensite (Ms) can start to form in a steel of a given composition. These two temperatures constitute the upper and lower limits at which the isothermal heat treatment can be performed to generate bainite.

It has been reported that bainitic ferrite plate thickness depends primarily on three parameters, i.e., (1) the strength of the austenite at the transformation temperature, (2) the dislocation density in the austenite and (3) the chemical free energy change accompanying transformation [1-3]. In accord, a strong austenite possessing a high dislocation density and a large driving force results in finer plates. Austenite strength and dislocation density refine the structure by increasing the resistance to interface motion, and the thermodynamic driving force refines the structure by increasing the nucleation rate. All three factors—austenite strength, dislocation density and driving force-increase 
as the transformation temperature decreases, so a lower bainite transformation temperature leads to a reduction in the thickness of the bainitic ferrite plates.

\section{Nanostructured Bainite}

The concept exploited in a new generation of bainitic steels was the strengthening of the parent austenite by alloying, among others with high $\mathrm{C}$ levels, and lowering the transformation temperature as much as possible to give the austenite a higher strength. On this basis, high carbon (0.6-1 wt. \%) high silicon (1.5-3 wt. \%) steels were designed to produce incredibly fine plates of bainitic ferrite, 20-40 nm thick, separated by a percolating network of retained austenite after transformation at 200-350 ${ }^{\circ} \mathrm{C}[4,5]$. The scale of this structure is such that it contains a remarkably large density of interfaces, making it very strong even without the presence of a substantial fraction of carbide precipitates. These steels present the highest strength/toughness combinations ever recorded in bainitic steels (2.5 GPa/30 MPa m ${ }^{1 / 2}$ ) [6-8]. Recently, in the frame of a Research Fund for Coal and Steel (RFCS) project [9], these microstructures demonstrated superior potential for abrasive wear applications in large components, where a uniform microstructure free from residual stresses or without complex processing is required. Likewise, it was confirmed through industrial testing, that these new grades are on a par with significantly more expensive abrasive wear-resistant alloy steels [10].

However, there are two issues that limit the scope for their wider exploitation. First, as the same theory used for the design of such alloys predicts, the transformation slows down dramatically as the transformation temperature is reduced, and it may take as long as 10 to $20 \mathrm{~h}$ to fully transform to bainite [4,5]. Second, due to their high carbon content, the steels are difficult to weld because of the formation of untempered, brittle martensite in the coarse grained heat affected zones of the joints.

\section{Transferring Nanostructured Bainite Concept}

Therefore, the open question is how to transfer the nanoscale bainite concept to lower C contents, with enhanced transformation kinetics and weldability, in order to allow broader application, without deteriorating the superior combination of the mechanical and technological properties too much.

So far, different approaches have been tried with different levels of success.

\subsection{Chemical Composition Modification}

One approach was to introduce significant quantities of $\mathrm{Mn}$ and $\mathrm{Ni},(2.3 \% \mathrm{Mn}$ and 5\% Ni wt. \%) to try to lower the Bs-Ms temperature range and solid solution strengthen the austenite while maintaining a low C content (0.1-0.2 wt. \%) [11]. It was found that the Bs temperature can indeed be suppressed in this way, but unlike the high carbon steels, the difference between Bs and Ms decreases drastically at high solute concentrations, see Figure 1. Furthermore, it has been suggested that the platelets of bainite tend to coalesce at low temperatures. This can be explained, theoretically, by an excess of available free energy during the transformation [12]. This coalescence counteracts the advantage of refining the bainite plates by their formation at low temperatures. The consequences of this coalescence on toughness are detrimental, but the influence on other properties requires further investigation [12-17].

In line with this approach, Soliman et al. [18] also reported the possibility of low temperature bainite in a $0.26 \mathrm{C}$ wt. \% steel heavily alloyed with $\mathrm{Mn}(3.44 \mathrm{wt}$. \%) and $\mathrm{Ni}(1.85 \mathrm{wt}$. \%) to suppress the transformation temperatures, $M s=285^{\circ} \mathrm{C}$; the alloy also contained Co and $\mathrm{Al}$ with the purpose of accelerating the transformation [19]. Final reported bainitic ferrite plate thicknesses were of the order of $150 \mathrm{~nm}$. The same authors performed a similar study [20] on higher C content steels $(0.4-0.5 \mathrm{C}$ wt. \%) with $\mathrm{Co}$ and $\mathrm{Al}$ among other alloying elements, bringing down the $\mathrm{Ms}$ to $210{ }^{\circ} \mathrm{C}$ and producing bainitic ferrite plates between 40 and $120 \mathrm{~nm}$. Qian et al. in their work [21] showed that in a 0.28C-1.96Mn-0.67Si-1.19Al-1.62Cr-0.34Ni-0.23Mo wt. \% steel, it was possible to obtain bainite at temperatures around $320^{\circ} \mathrm{C}$, but there is no report of the scale of the microstructure. 


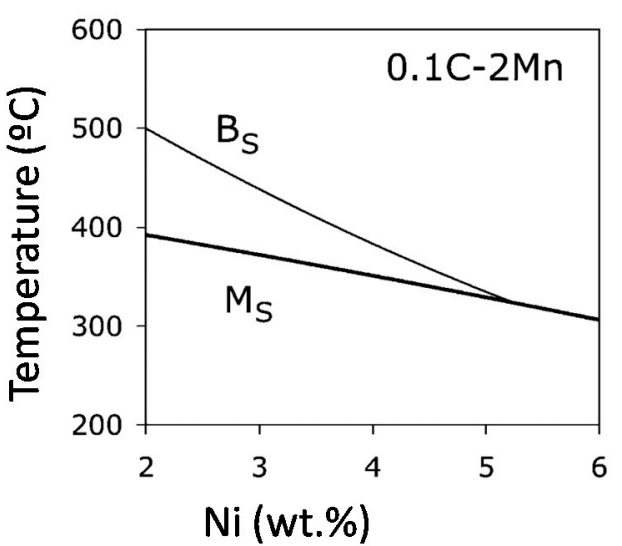

(a)

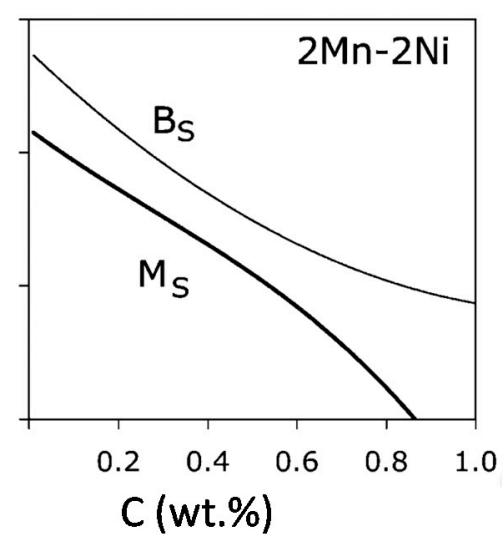

(b)

Figure 1. Thermodynamics calculation of bainite and martensite start transformation temperatures: (a) effect of $\mathrm{Ni}$ in Fe-0.1C-2Mn (wt. \%) alloy system; (b) effect of C in Fe-2Mn-2Ni (wt. \%) alloy system. Adapted from [11].

Wang et al. [22] and Long et al. [23] investigated an alloy (34MnSi-CrAlNiMo) containing 0.35C-1.5Si-1.5Mn-0.8Al-1.15Cr-0.4Mo all in wt. \%. The measured Ms was found to be $310{ }^{\circ} \mathrm{C}$ and accordingly isothermal holding at 320-380 ${ }^{\circ} \mathrm{C}$ was applied to obtain bainite. The obtained microstructure was indeed a fine mixture of bainitic ferrites plates interwoven with thin films of retained austenite, see results of the measured bainitic ferrite plate and retained austenite film thickness, $t_{\mathrm{BF}}$ and $t_{\mathrm{Ar}}$ respectively, in Figure 2.

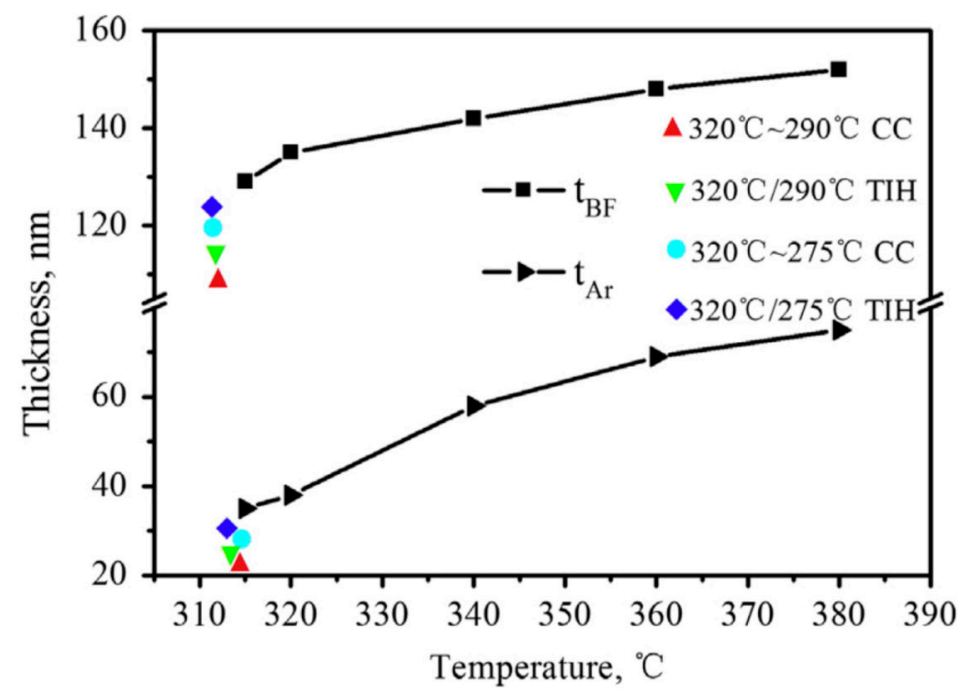

Figure 2. Relationship between $t_{\mathrm{BF}}, t_{\mathrm{Ar}}$ and transformation temperature in $34 \mathrm{MnSi}-\mathrm{CrAlNiMo}$ steel. TIH stands for Two Isothermal holding and CC for continuous cooling. Extracted from reference [23]. Reproduced with permission from Elsevier, 2017.

It is necessary to highlight that, in most of those works, the focus is put on attaining low temperature bainite, thus assuming that it will lead to nanostructured bainitic ferrite, which is not always the case. As already pointed out, low transformation temperatures will lead to a nanostructured bainite provided that the austenite from where bainite grows is sufficiently strong. 


\subsection{Heat Treatment Variations}

There is another approach that aims at obtaining nanostructured bainite by the development of resourceful heat treatments. Wang et al. [24] by means of a multistep heat treatment, shown in Figure 3, managed to obtain an average plate thickness as low as $110 \mathrm{~nm}$ in a 0.30C-1.46Si-1.97Mn-1.50Ni-0.30Cr-0.96Cu-0.25Mo wt. \% alloy. The concept lying beneath this multistep treatment is the continuous increase in the austenite $C$ content due to partial bainitic transformation after each step, so that in the final steps, bainite will grow from an austenite whose $C$ content is greater than that of the bulk, which also allows to carry on those final steps at temperatures that are lower than the Ms of the bulk alloy, but higher than the estimated Ms of the partially untransformed carbon-enriched austenite.

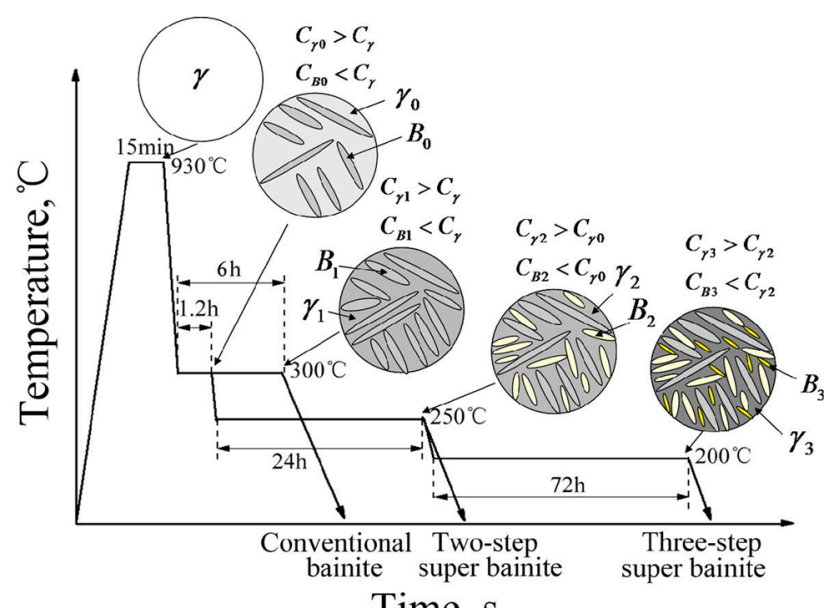

Time, s

Figure 3. Heat treatment cycles and resultant microstructures during a multi-step low-temperature super-bainite transformation. Extracted from reference [24]. Reproduced with permission from Elsevier, 2017.

In line with this partial $\mathrm{C}$ enrichment of austenite to promote finer bainite, Li et al. [25] proposed a novel quenching and dynamic partitioning (Q-DP) process to obtain a fine microstructure comprising martensite-bainite laths and thin films of interlath retained austenite, in a medium $\mathrm{C}$ steel $(0.3 \mathrm{C}$ wt. \%). The applied process is schematically shown in Figure 4.
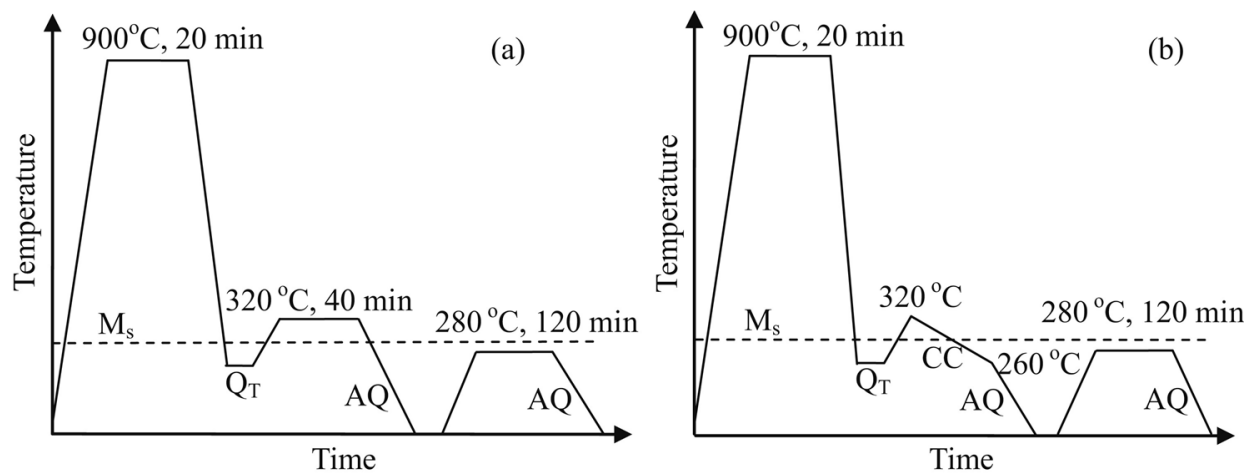

Figure 4. Different heat treatment processes used (a) Q\&P process, (b) Q-DP process; QT: quenching temperature, CC: continuous cooling, AQ: air quenching. Extracted from reference [25]. Reproduced with permission from Elsevier, 2017.

Given that there exists the possibility of forming bainite by isothermal transformation at temperatures below the Ms [26-33], this is also becoming an attractive alternative, not only to accelerate 
the bainitic transformation, but also to obtain a finer microstructure in later stages of transformation. Figure 5 shows an example for 0.15 and $0.28 \mathrm{C}$ steels transformed to bainite below the $\mathrm{Ms}$; the author reports a decrease in the bainitic ferrite plate thickness of almost $40 \mathrm{~nm}$ in both cases, the final plate thickness being around 140-200 nm [26]. Bainite reaction occurs, after formation of some fraction of martensite, in a virtually identical manner as it would if that first transformed fraction had been obtained through isothermal bainite reaction. This is consistent with an autocatalytic effect that is identical whether one considers the influence of existing martensite or bainite laths on subsequent bainite lath nucleation [34].
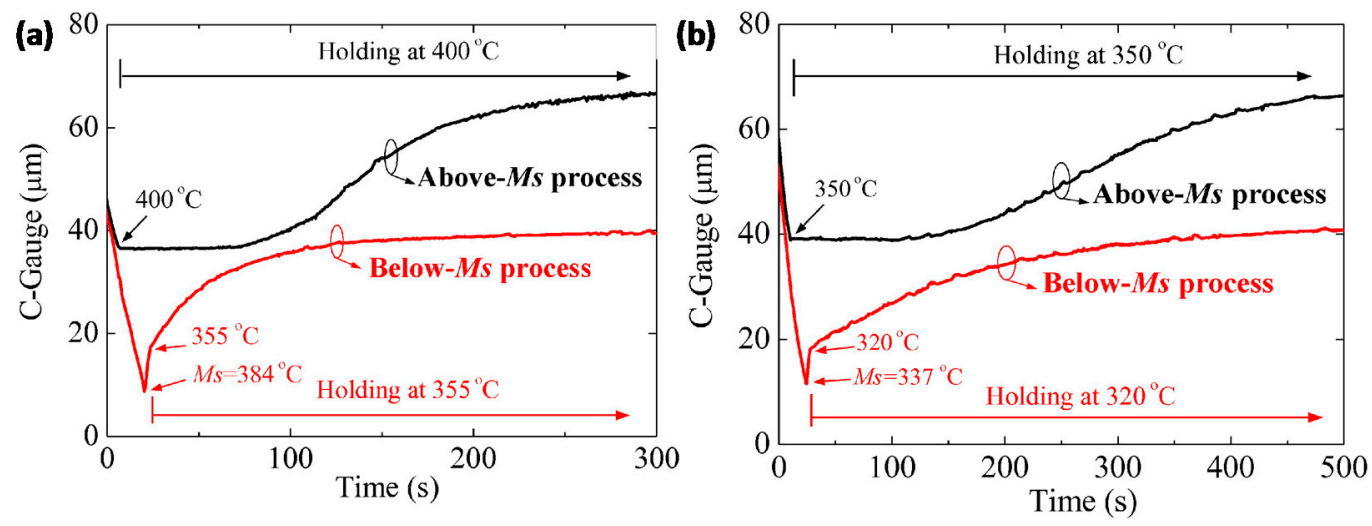

Figure 5. Dilation-time curves of $0.15 \mathrm{C}$ wt. \% steel (a), and $0.28 \mathrm{C}$ wt. \% steel (b) during cooling according to the above- and below-Ms austempering processes. Extracted from reference [26]. Reproduced with permission from Elsevier, 2017.

The reason why blocky austenite is undesirable is due to the fact that it has a lower chemical and mechanical stability and transforms to fresh, brittle high-carbon martensite absorbing low loads during toughness testing, thereby reducing the toughness. Bhadeshia and Edmonds [35] showed that desirable impact toughness was achieved in high-silicon bainitic steels containing films instead of blocks of retained austenite. Therefore, replacing austenitic blocks with a lath-like morphology is essential to improve steel toughness. Using multi-step isothermal bainite transformation in a medium carbon steel (0.30C-1.46Si-1.97Mn-1.50Ni-0.30Cr-0.96Cu-0.25Mo all in wt. \%), Wang et al. [24] could almost eliminate the formation of blocky austenite through first partially transformed conventional low temperature bainite $\left(300{ }^{\circ} \mathrm{C} / 1.2 \mathrm{~h}\right)$, followed by the formation of higher volumes of nanoscale bainitic ferrite plates and retaining film-like austenite at still lower transformation temperatures (at 250/24 h and $200{ }^{\circ} \mathrm{C} / 72 \mathrm{~h}$ ), with a concomitant improvement in mechanical properties. A similar approach was adopted by Kim et al. [36]. On a 0.3C-1.5Si-1.5Mn wt. \% steel and previously by Hase et al. [37] in developing nanostructured bainitic steel. They also reported an increase of the austenite content with thin film morphology and better ductility behaviour. It is even more important in case of coiled strips in industrial rolling, where microstructures comprising a range of bainitic lath thicknesses can form as cooling progresses. In yet another study on a 30MnSiCrAlNiMo 0.3C wt. \% steel, Long et al. [38] showed that continuous cooling from $\mathrm{Ms}+10{ }^{\circ} \mathrm{C}$ to $\mathrm{Ms}-20{ }^{\circ} \mathrm{C}$ at the cooling rate of $0.5{ }^{\circ} \mathrm{C} / \mathrm{min}$ produced fine plates of carbide free bainitic ferrite with thin films of retained austenite giving the best mechanical properties of any microstructures for the investigated steel.

\subsection{Prior Autenite Grain Size Control (No Deformation)}

Another set of approaches takes advantage of the fact that the Ms temperature decreases as the prior austenite grain size (PAGS) becomes smaller [39-42]. It is argued that this behavior is caused by grain boundary strengthening of the austenite, which makes martensite nucleation more difficult by providing a greater resistance to the motion of dislocations involved in the nucleation 
process comparable to the effect that solid solution strengthening has on the nucleation of martensite and bainite.

Conceptually, this idea can be summarized in the following sequence: the free energy change for the transformation of austenite to martensite must reach a critical value at the martensite start temperature (Ms), $\Delta G^{\gamma \alpha}<\Delta G_{M s}$. Thus, when the PAGS decreases, there is a component of strengthening of the austenite that adds a mechanical component to the free energy change $\Delta G^{\gamma \alpha}+\Delta G_{M E C H}<\Delta G_{M s}$.

Figure 6 shows that the reduction of the transformation temperature is most pronounced when the PAGS $<10 \mu \mathrm{m}[39,40]$.
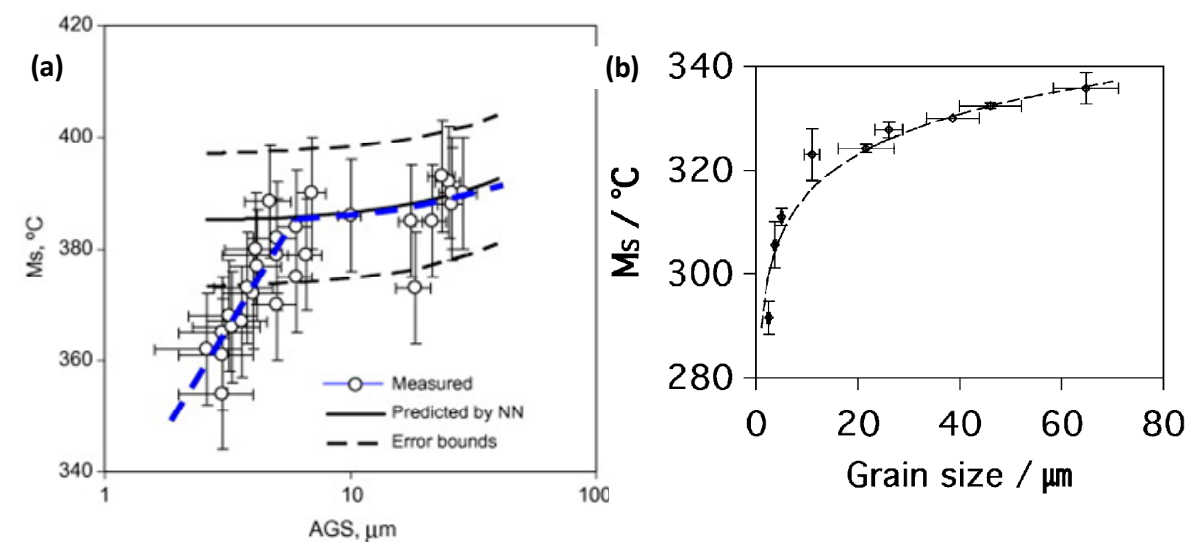

Figure 6. Influence of prior austenite grain size (PAGS) on the Ms temperature (a) comparison of experimental results and those obtained by a Neural Network model from reference [39]. Reproduced with permission from Elsevier, 2017. And (b) experimental work from reference [40]. Reproduced with permission from Elsevier, 2017.

In this sense, controlling and decreasing the austenitization temperature and time would affect the $M s$ temperature but only via the associated variation in austenite grain size. A very interesting side effect of the reduction of the PAGS is the associated increase in the bainite transformation kinetics, due to the increase in the number density of austenite grain surface nucleation sites. Consequently, there is a refinement of the size of the bainitic ferrite plates themselves, because an increase in the driving force stimulates a greater number density of plates [1,19].

\subsection{Deformation of Austenite (AUSFORMING)}

The option of applying a thermomechanical treatment to modify the PAGS also exists, where the combination of plastic deformation and precipitation on the nanoscale has been widely used in steels to control the prior austenite grain size at the micron level [43-45]. The most successful example is controlled rolling, with accelerated cooling for plates of low-C steels [43]. Although, in that particular case, the ultimate target of refinement is equiaxed ferrite, the principles remain the same. A decrease of the PAGS by controlled nucleation and growth of the recrystallized austenite and enhancement of the potent nucleation sites for ferrite, i.e., shear bands, dislocation substructures and stepped grain boundaries, has led to a minimum average ferrite grain size of $5 \mu \mathrm{m}$ [43]. A combination of large-strain within the warm deformation regime and subsequent intercritical annealing, facilitate the formation of a dual phase microstructure with micron-sized ferrite [46].

From literature, it is clear that the studied thermomechanical routes can be divided into two groups: one, where the deformation is applied to austenite at high temperatures (above or below the recrystallization stop temperature and even in the warm deformation regime), and the other group, where deformation is applied to austenite at low temperatures, more precisely in the bay between the 
C-curves of ferrite and bainite in the TTT (Time Temperature Transformation) diagram. Examples of both routes can be found in Figure 7.
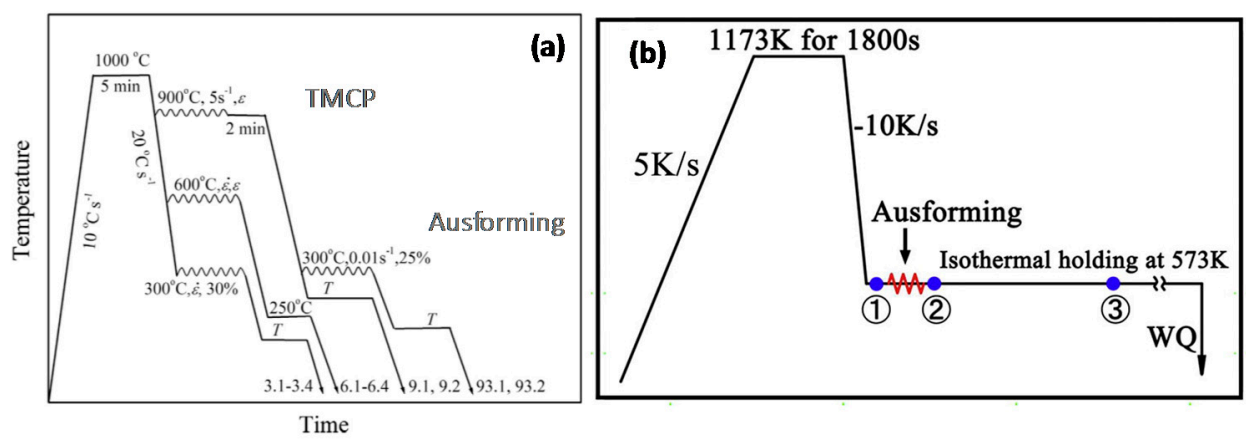

Figure 7. Examples of thermomechanical treatment applied to austenite prior to bainitic transformation. Extracted from references [47,48]. Reproduced with permission from Elsevier, 2017.

This same technique has received attention as a means of accelerating the sluggish bainitic transformation of (low temperature) nanostructured bainite and hence, different deformation routes have been tested, not only revealing accelerated transformation kinetics but also achieving an extra refinement of the microstructure [47-59]. While extensive work has been done on a single alloy containing 0.5 C wt. \% [47,49,60-63], only in the case of Refs. [56,64], the carbon content was lowered to $0.2 \mathrm{wt}$. \%. A summary of the microstructural characterization after ausforming at different temperatures prior to austempering at $355^{\circ} \mathrm{C}\left(<M s=384{ }^{\circ} \mathrm{C}\right)$ in a $0.15 \mathrm{C}$ steel is shown in Figure 8.

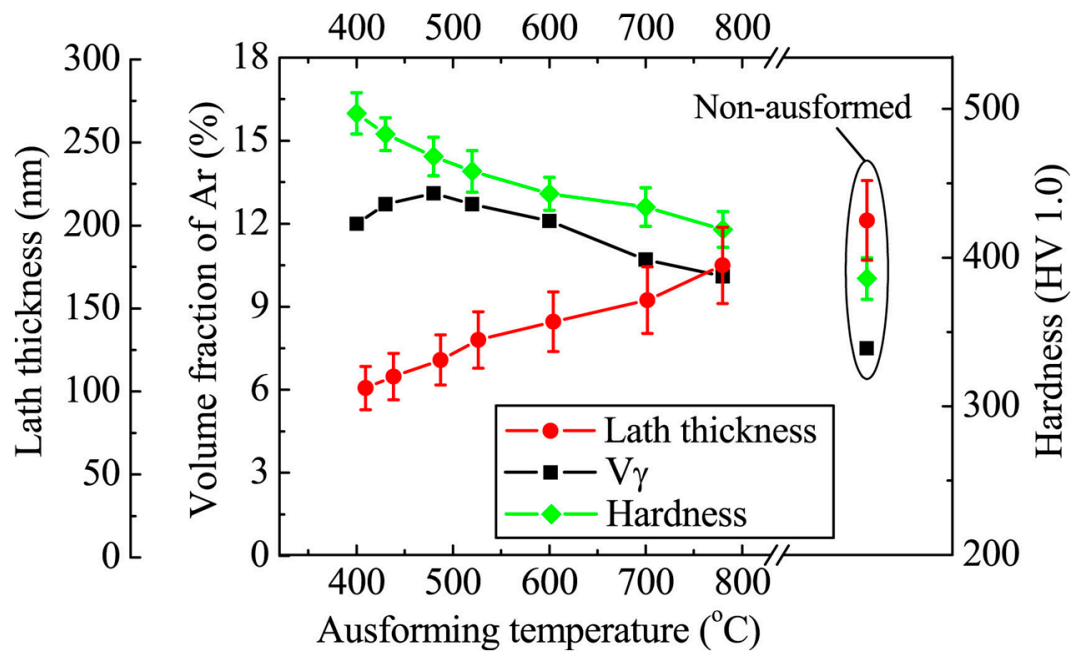

Figure 8. Average thickness of bainitic laths, volume fraction of retained austenite (Ar) and Vickers hardness as a function of ausforming temperature. The data for the non-ausformed sample are also shown for comparison. Extracted from reference [64]. Reproduced with permission from Elsevier, 2017.

An advantage of the low temperature process as compared with the higher temperature one is that the former can be employed to drastically reduce the number of bainite variants in a single austenite grain, leading to a reduction in the fraction of detrimental block-type retained austenite and an increase in the fraction of beneficial interlath films of retained austenite $[48,50]$. Gong et al. [48,50] studied the effects of ausforming temperature on bainite transformation and variant selection in high-carbon nanobainitic steel. Their results indicated that ausforming at a low temperature $\left(300^{\circ} \mathrm{C}\right)$ can accelerate bainite transformation and produce a strong variant selection, whereas ausforming at a high temperature $\left(600^{\circ} \mathrm{C}\right)$ has a weak influence. 
Ausforming has also been shown to extend the temperature range available for isothermal transformation to bainite. Zhang et al. [47] showed that ausforming decreased the $M s$, thereby enabling isothermal transformation at lower temperatures, thus facilitating the formation of nanostructured bainite. Besides this, decreasing the ausforming temperature and increasing the ausforming strain reduced the incubation time for bainite, refined the bainite lath size and enhanced the hardness. The decrease of $M s$ is explained by the mechanical part of the free energy change $\left(\triangle G_{M E C H}\right)$.

\subsection{Considerations}

The decrease in Ms caused by ausforming and the consequent decrease in the transformation kinetics due to the decrease in the transformation temperature, would be compensated by the increased number of potent nucleation sites for bainite, grain boundary surface per volume unit and dislocations [19,47]. However, this same acceleration effect would also affect the reconstructive transformation to ferrite. Overall, it is therefore expected that ausforming will produce a general displacement of the CCT and TTT curves to shorter times provided that the dislocation density in the austenite is not too high.

The displacive transformations of austenite to martensite and bainite involve the coordinated movement of atoms across semicoherent glissile interfaces. Such movements cannot be sustained across grain boundaries, due to the loss of coherency, and therefore martensite and bainite plates are limited to single prior austenite grains. Isolated dislocations also hinder the progress of glissile interfaces, but they can often be accommodated by the transformation. However, it is well established $[65,66]$ that if the strain in the austenite becomes sufficiently large, the motion of glissile interfaces becomes impossible, causing the transformation to halt. This applies to all cases involving the movement of glissile interfaces, whether their motion leads to a phase change $[35,67]$ or simply to a reorientation of the lattice as occurs in mechanical twinning [68]. Therefore, sufficiently high dislocation densities in the austenite result in what is referred to as mechanical stabilization of the austenite [69-72], and it can lead to a complete cessation of transformation. Therefore, it is possible to define the critical strain for mechanical stabilization, as the strain necessary to apply to austenite so it is stabilized against bainitic or martensitic transformation [69]. Figure 9 shows an example of such calculations for a 316L stainless steel heavily alloyed with $\mathrm{Ni}$, far away from the typical chemical compositions of bainitic steels but still representative of the existing problem with the mechanical stabilization of austenite.

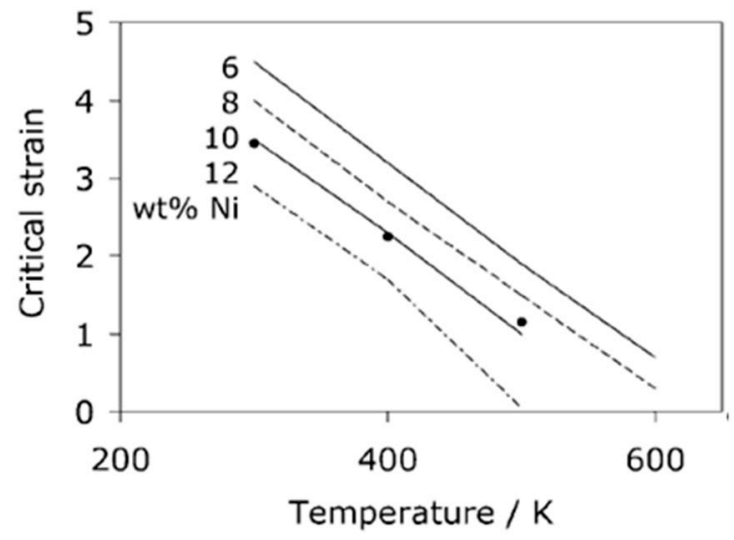

Figure 9. Critical values of plastic strain for mechanical stabilization of austenite in a 316L austenitic stainless steel. Extracted from reference [69]. Reproduced with permission from Taylor \& Francis, 2017.

\section{Conclusions}

The nanostructured bainite concept invariably needs a strong austenite from where bainitic ferrite plates will grow. The advantages of transferring the nanoscale bainite concept to lower $C(0.4-0.5 \mathrm{wt}$. \%) 
contents than those originally used for these types of alloys ( $1 \mathrm{wt}$. \% C), would be to have alloys with enhanced transformation kinetics and weldability, allowing for much broader applications.

This work has revised different approaches that have pursued such an aim, including the most recent and novel, ausforming, where austenite is plastically deformed before bainitic transformation. Therefore, in accord with the literature review, to date, there does not exist a detailed study, where alloy design, process parameters, microstructure and mechanical response are investigated in order to obtain nanostructured bainite in a variety of medium $C$ steels in conjunction with the ausforming process. Such a study is the subject of an ongoing project RFCS-2015-709607 that is expected to conclude with a recommendation of alloy chemical compositions and process parameters for industrial full-scale production.

Acknowledgments: The authors gratefully acknowledge the support of the European Research Fund for Coal and Steel for funding this research under the contracts RFCS-2015-709607.

Conflicts of Interest: The authors declare no conflict of interest.

\section{References}

1. Singh, S.B.; Bhadeshia, H.K.D.H. Estimation of bainite plate-thickness in low-alloy steels. Mater. Sci. Eng. A 1998, 245, 72-79. [CrossRef]

2. Cornide, J.; Garcia-Mateo, C.; Capdevila, C.; Caballero, F.G. An assessment of the contributing factors to the nanoscale structural refinement of advanced bainitic steels. J. Alloys Compd. 2013, 577, S43-S47. [CrossRef]

3. Caballero, F.G.; Garcia-Mateo, C.; Sourmail, T. Bainitic steel: Nanostructured. In Encyclopedia of Iron, Steel, and Their Alloys; Taylor \& Francis Inc.: Abingdon, UK, 2016; pp. 271-290.

4. Garcia-Mateo, C.; Caballero, F.G.; Sourmail, T.; Smanio, V.; Garcia de Andres, C. Industrialised nanocrystalline bainitic steels. Design approach. Int. J. Mater. Res. 2014, 105, 725-734. [CrossRef]

5. Garcia-Mateo, C.; Sourmail, T.; Caballero, F.G.; Smanio, V.; Kuntz, M.; Ziegler, C.; Leiro, A.; Vuorinen, E.; Elvira, R.; Teeri, T. Nanostructured steel industrialisation: Plausible reality. Mater. Sci. Technol. 2014, 30, 1071-1078. [CrossRef]

6. Caballero, F.G.; Bhadeshia, H.K.D.H.; Mawella, K.J.A.; Jones, D.G.; Brown, P. Very strong low temperature bainite. Mater. Sci. Technol. 2002, 18, 279-284. [CrossRef]

7. Garcia-Mateo, C.; Caballero, F.G. Ultra-high-strength bainitic steels. ISIJ Int. 2005, 45, 1736-1740. [CrossRef]

8. Garcia-Mateo, C.; Caballero, F.G.; Sourmail, T.; Kuntz, M.; Cornide, J.; Smanio, V.; Elvira, R. Tensile behaviour of a nanocrystalline bainitic steel containing $3 \mathrm{wt} \%$ silicon. Mater. Sci. Eng. A 2012, 549, 185-192. [CrossRef]

9. Sourmail, T.; Smanio, V.; Ziegler, C.; Heuer, V.; Kuntz, M.; Caballero, F.G.; Garcia-Mateo, C.; Cornide, J.; Elvira, R.; Leiro, A.; et al. Novel Nanostructured Bainitic Steel Grades to Answer the Need for High-Performance Steel Components (Nanobain); Rfsr-ct-2008-00022; European Commission: Luxembourg, 2013; p. 129.

10. Leiro, A.; Vuorinen, E.; Sundin, K.G.; Prakash, B.; Sourmail, T.; Smanio, V.; Caballero, F.G.; Garcia-Mateo, C.; Elvira, R. Wear of nano-structured carbide-free bainitic steels under dry rolling-sliding conditions. Wear 2013, 298, 42-47. [CrossRef]

11. Yang, H.S.; Bhadeshia, H.K.D.H. Designing low carbon, low temperature bainite. Mater. Sci. Technol. 2008, 24, 335-342. [CrossRef]

12. Ohmori, Y.; Ohtsubo, H.; Jung, Y.C.; Okaguchi, S.; Ohtani, H. Morphology of bainite and widmanstätten ferrite. Metall. Mater. Trans. A 1994, 25, 1981-1989. [CrossRef]

13. Pak, J.; Suh, D.W.; Bhadeshia, H.K.D.H. Promoting the coalescence of bainite platelets. Scr. Mater. 2012, 66, 951-953. [CrossRef]

14. Bhadeshia, H.K.D.H.; Keehan, E.; Karlsson, L.; Andrén, H.O. Coalesced bainite. Trans. Indian Inst. Met. 2006, 59, 689-694.

15. Keehan, E.; Karlsson, L.; Andren, H.O. Influence of carbon, manganese and nickel on microstructure and properties of strong steel weld metals: Part 1-Effect of nickel content. Sci. Technol. Weld. Join. 2006, 11, 1-8. [CrossRef]

16. Pak, J.H.; Bhadeshia, H.K.D.H.; Karlsson, L.; Keehan, E. Coalesced bainite by isothermal transformation of reheated weld metal. Sci. Technol. Weld. Join. 2008, 13, 593-597. [CrossRef] 
17. Caballero, F.G.; Chao, J.; Cornide, J.; Garcia-Mateo, C.; Santofimia, M.J.; Capdevila, C. Toughness deterioration in advanced high strength bainitic steels. Mater. Sci. Eng. A 2009, 525, 87-95. [CrossRef]

18. Soliman, M.; Mostafa, H.; El-Sabbagh, A.S.; Palkowski, H. Low temperature bainite in steel with 0.26 wt $\%$ C. Mater. Sci. Eng. A 2010, 527, 7706-7713. [CrossRef]

19. Garcia-Mateo, C.; Caballero, F.; Bhadeshia, H. Acceleration of low-temperature bainite. ISIJ Int. 2003, 43, 1821-1825. [CrossRef]

20. Soliman, M.; Palkowski, H. Ultra-fine bainite structure in hypo-eutectoid steels. ISIJ Int. 2007, 47, $1703-1710$. [CrossRef]

21. Qian, L.; Zhou, Q.; Zhang, F.; Meng, J.; Zhang, M.; Tian, Y. Microstructure and mechanical properties of a low carbon carbide-free bainitic steel co-alloyed with Al and Si. Mater. Des. 2012, 39, 264-268. [CrossRef]

22. Wang, Y.H.; Zhang, F.C.; Wang, T.S. A novel bainitic steel comparable to maraging steel in mechanical properties. Scr. Mater. 2013, 68, 763-766. [CrossRef]

23. Long, X.Y.; Kang, J.; Lv, B.; Zhang, F.C. Carbide-free bainite in medium carbon steel. Mater. Des. 2014, 64, 237-245. [CrossRef]

24. Wang, X.L.; Wu, K.M.; Hu, F.; Yu, L.; Wan, X.L. Multi-step isothermal bainitic transformation in medium-carbon steel. Scr. Mater. 2014, 74, 56-59. [CrossRef]

25. Li, Q.; Huang, X.; Huang, W. Microstructure and mechanical properties of a medium-carbon bainitic steel by a novel quenching and dynamic partitioning (Q-DP) process. Mater. Sci. Eng. A 2016, 662, 129-135. [CrossRef]

26. Zhao, L.; Qian, L.; Meng, J.; Zhou, Q.; Zhang, F. Below-Ms austempering to obtain refined bainitic structure and enhanced mechanical properties in low-C high-Si/Al steels. Scr. Mater. 2016, 112, 96-100. [CrossRef]

27. Da Silva, E.P.; De Knijf, D.; Xu, W.; Föjer, C.; Houbaert, Y.; Sietsma, J.; Petrov, R. Isothermal transformations in advanced high strength steels below martensite start temperature. Mater. Sci. Technol. 2015, 31, 808-816. [CrossRef]

28. Hofer, C.; Leitner, H.; Winkelhofer, F.; Clemens, H.; Primig, S. Structural characterization of "carbide-free" bainite in a Fe-0.2C-1.5Si-2.5Mn steel. Mater. Charact. 2015, 102, 85-91. [CrossRef]

29. Yoshikawa, N.; Kobayashi, J.; Sugimoto, K.-I. Notch-fatigue properties of advanced trip-aided bainitic ferrite steels. Metall. Mater. Trans. A 2012, 43, 4129-4136. [CrossRef]

30. Sugimoto, K.I. Fracture strength and toughness of ultra high strength trip aided steels. Mater. Sci. Technol. 2009, 25, 1108-1117. [CrossRef]

31. Kolmskog, P.; Borgenstam, A.; Hillert, M.; Hedström, P.; Babu, S.S.; Terasaki, H.; Komizo, Y.I. Direct observation that bainite can grow below Ms. Metall. Mater. Trans. A 2012, 43, 4984-4988. [CrossRef]

32. van Bohemen, S.M.C.; Santofimia, M.J.; Sietsma, J. Experimental evidence for bainite formation below Ms in Fe-0.66C. Scr. Mater. 2008, 58, 488-491. [CrossRef]

33. Samanta, S.; Biswas, P.; Giri, S.; Singh, S.B.; Kundu, S. Formation of bainite below the Ms temperature: Kinetics and crystallography. Acta Mater. 2016, 105, 390-403. [CrossRef]

34. Smanio, V.; Sourmail, T. Effect of partial martensite transformation on bainite reaction kinetics in different 1\%C steels. Solid State Phenom. 2011, 172-174, 821-826. [CrossRef]

35. Bhadeshia, H.K.D.H.; Edmonds, D.V. Bainite in silicon steels: New composition-property approach. Part 2. Met. Sci. 1983, 17, 420-425. [CrossRef]

36. Kim, K.W.; Il Kim, K.; Lee, C.H.; Kang, J.Y.; Lee, T.H.; Cho, K.M.; Oh, K.H. Control of retained austenite morphology through double bainitic transformation. Mater. Sci. Eng. A 2016, 673, 557-561. [CrossRef]

37. Hase, K.; Garcia-Mateo, C.; Bhadeshia, H.K.D.H. Bimodal size-distribution of bainite plates. Mater. Sci. Eng. A 2006, 438, 145-148. [CrossRef]

38. Long, X.Y.; Zhang, F.C.; Kang, J.; Lv, B.; Shi, X.B. Low-temperature bainite in low-carbon steel. Mater. Sci. Eng. A 2014, 594, 344-351. [CrossRef]

39. García-Junceda, A.; Capdevila, C.; Caballero, F.G.; de Andrés, C.G. Dependence of martensite start temperature on fine austenite grain size. Scr. Mater. 2008, 58, 134-137. [CrossRef]

40. Yang, H.-S.; Bhadeshia, H.K.D.H. Austenite grain size and the martensite-start temperature. Scr. Mater. 2009, 60, 493-495. [CrossRef]

41. Lee, S.-J.; Park, K.-S. Prediction of martensite start temperature in alloy steels with different grain sizes. Metall. Mater. Trans. A 2013, 44, 3423-3427. [CrossRef] 
42. Yang, H.S.; Suh, D.W.; Bhadeshia, H.K.D.H. More complete theory for the calculation of the martensite-start temperature in steels. ISIJ Int. 2012, 52, 164-166. [CrossRef]

43. Maki, T. Current state and future prospect of microstructure control in steels. Tetsu To Hagane-J. ISIJ 1995, 81, N547-N555. [CrossRef]

44. Krauss, G. Steels: Heat Treatment and Processing Principles; ASM International: Materials Park, OH, USA, 1989.

45. Calcagnotto, M.; Ponge, D.; Raabe, D. Effect of grain refinement to $1 \mu \mathrm{m}$ on strength and toughness of dual-phase steels. Mater. Sci. Eng. A 2010, 527, 7832-7840. [CrossRef]

46. Calcagnotto, M.; Adachi, Y.; Ponge, D.; Raabe, D. Deformation and fracture mechanisms in fine- and ultrafine-grained ferrite/martensite dual-phase steels and the effect of aging. Acta Mater. 2011, 59, 658-670. [CrossRef]

47. Zhang, M.; Wang, Y.H.; Zheng, C.L.; Zhang, F.C.; Wang, T.S. Effects of ausforming on isothermal bainite transformation behaviour and microstructural refinement in medium-carbon Si-Al-rich alloy steel. Mater. Des. 2014, 62, 168-174. [CrossRef]

48. Gong, W.; Tomota, Y.; Adachi, Y.; Paradowska, A.M.; Kelleher, J.F.; Zhang, S.Y. Effects of ausforming temperature on bainite transformation, microstructure and variant selection in nanobainite steel. Acta Mater. 2013, 61, 4142-4154. [CrossRef]

49. Zhang, M.; Wang, T.S.; Wang, Y.H.; Yang, J.; Zhang, F.C. Preparation of nanostructured bainite in medium-carbon alloy steel. Mater. Sci. Eng. A 2013, 568, 123-126. [CrossRef]

50. Gong, W.; Tomota, Y.; Koo, M.S.; Adachi, Y. Effect of ausforming on nanobainite steel. Scr. Mater. 2010, 63, 819-822. [CrossRef]

51. Chakraborty, J.; Bhattacharjee, D.; Manna, I. Development of ultrafine bainite + martensite duplex microstructure in sae 52100 bearing steel by prior cold deformation. Scr. Mater. 2009, 61, 604-607. [CrossRef]

52. Chakraborty, J.; Manna, I. Development of ultrafine ferritic sheaves/plates in sae 52100 steel for enhancement of strength by controlled thermomechanical processing. Mater. Sci. Eng. A 2012, 548, 33-42. [CrossRef]

53. Lonardelli, I.; Bortolotti, M.; Van Beek, W.; Girardini, L.; Zadra, M.; Bhadeshia, H.K.D.H. Powder metallurgical nanostructured medium carbon bainitic steel: Kinetics, structure, and in situ thermal stability studies. Mater. Sci. Eng. A 2012, 555, 139-147. [CrossRef]

54. Zhang, M.; Wang, Y.H.; Zheng, C.L.; Zhang, F.C.; Wang, T.S. Austenite deformation behavior and the effect of ausforming process on martensite starting temperature and ausformed martensite microstructure in medium-carbon Si-Al-rich alloy steel. Mater. Sci. Eng. A 2014, 596, 9-14. [CrossRef]

55. He, J.; Zhao, A.; Huang, Y.; Zhi, C.; Zhao, F. Acceleration of Bainite Transformation at Low Temperature by Warm Rolling Process. Mater. Today Proc. 2015, 2, S289-S294. [CrossRef]

56. Timokhina, I.; Beladi, H.; Xiong, X.; Hodgson, P. Effect of composition and processing parameters on the formation of nano-bainite in advanced high strength steels. J. Iron Steel Res. Int. 2011, 18, $238-241$.

57. Golchin, S.; Avishan, B.; Yazdani, S. Effect of $10 \%$ ausforming on impact toughness of nano bainite austempered at $300^{\circ}$ C. Mater. Sci. Eng. A 2016, 656, 94-101. [CrossRef]

58. He, J.; Zhao, A.; Zhi, C.; Fan, H. Acceleration of nanobainite transformation by multi-step ausforming process. Scr. Mater. 2015, 107, 71-74. [CrossRef]

59. Kabirmohammadi, M.; Avishan, B.; Yazdani, S. Transformation kinetics and microstructural features in low-temperature bainite after ausforming process. Mater. Chem. Phys. 2016, 184, 306-317. [CrossRef]

60. Zhou, M.; Xu, G.; Wang, L.; Hu, H. Combined effect of the prior deformation and applied stress on the bainite transformation. Met. Mater. Int. 2016, 22, 956-961. [CrossRef]

61. Zhi, C.; Zhao, A.; He, J.; Yang, H.; Qi, L. Effects of the multi-step ausforming process on the microstructure evolution of nanobainite steel. In Proceedings of the International Conference on Advanced Materials, Structures and Mechanical Engineering, Incheon, Korea, 29-31 May 2015; Kaloop, M., Ed.; CRC Press: Boca Raton, FL, USA, 2016; pp. 399-403.

62. Zhou, M.; Xu, G.; Zhang, Y.; Xue, Z. The effects of external compressive stress on the kinetics of low temperature bainitic transformation and microstructure in a superbainite steel. Int. J. Mater. Res. 2015, 106, 1040-1045. [CrossRef]

63. Hu, H.; Xu, G.; Wang, L.; Zhou, M. Effects of strain and deformation temperature on bainitic transformation in a Fe-C-Mn-Si alloy. Steel Res. Int. 2016, 88. [CrossRef] 
64. Zhao, L.; Qian, L.; Liu, S.; Zhou, Q.; Meng, J.; Zheng, C.; Zhang, F. Producing superfine low-carbon bainitic structure through a new combined thermo-mechanical process. J. Alloys Compd. 2016, 685, 300-303. [CrossRef]

65. Tsuzaki, K.; Fukasaku, S.-I.; Tomota, Y.; Maki, T. Effect of prior deformation of austenite on the $\gamma \rightarrow \varepsilon$ martensitic transformation in Fe-Mn alloys. Mater. Trans. JIM 1991, 32, 222-228. [CrossRef]

66. Bhadeshia, H.K.D.H. The bainite transformation: Unresolved issues. Mater. Sci. Eng. A 1999, 273-275, 58-66. [CrossRef]

67. Shipway, P.H.; Bhadeshia, H.K.D.H. The mechanical stabilisation of widmanstatten ferrite. Mater. Sci. Eng. A 1997, 223, 179-185. [CrossRef]

68. Christian, J.W.; Mahajan, S. Deformation twinning. Prog. Mater. Sci. 1995, 39, 1-157. [CrossRef]

69. Chatterjee, S.; Wang, H.S.; Yang, J.R.; Bhadeshia, H.K.D.H. Mechanical stabilisation of austenite. Mater. Sci. Technol. 2006, 22, 641-644. [CrossRef]

70. Shipway, P.H.; Bhadeshia, H.K.D.H. Mechanical stabilisation of bainite. Mater. Sci. Technol. 1995, 11, 1116-1128. [CrossRef]

71. Maalekian, M.; Kozeschnik, E.; Chatterjee, S.; Bhadeshia, H.K.D.H. Mechanical stabilisation of eutectoid steel. Mater. Sci. Technol. 2007, 23, 610-612. [CrossRef]

72. Yi, H.L.; Lee, K.Y.; Bhadeshia, H.K.D.H. Mechanical stabilisation of retained austenite in $\delta$-trip steel. Mater. Sci. Eng. A 2011, 528, 5900-5903. [CrossRef]

(C) 2017 by the authors. Licensee MDPI, Basel, Switzerland. This article is an open access article distributed under the terms and conditions of the Creative Commons Attribution (CC BY) license (http:/ / creativecommons.org/licenses/by/4.0/). 